\title{
Microclimatic Conditions Mediate The Effect of Deadwood and Forest Characteristics On a Threatened Beetle Species, Tragosoma Depsarium
}

Ly Lindman ( $\sim$ LyLindman@gmail.com )

Sveriges lantbruksuniversitet https://orcid.org/0000-0003-2724-2424

Erik Öckinger

Sveriges lantbruksuniversitet

Thomas Ranius

Sveriges lantbruksuniversitet

\section{Research Article}

Keywords: data-logger, habitat, humidity, saproxylic, temperature

Posted Date: October 21st, 2021

DOI: https://doi.org/10.21203/rs.3.rs-736472/v1

License: (c) (i) This work is licensed under a Creative Commons Attribution 4.0 International License.

Read Full License 
1 Microclimatic conditions mediate the effect of deadwood and forest characteristics on a

2 threatened beetle species, Tragosoma depsarium

3 Ly Lindman, Erik Öckinger, Thomas Ranius

4 Swedish University of Agricultural Sciences, Dept. of Ecology, Box 7044, 75007 Uppsala, Sweden

5 Corresponding author: L. Lindman, e-mail: Ly.Lindman@ @lu.se, tel: +46-70-5671777

6

\section{Abstract}

8 While climate change has increased interest in the influence of microclimate on many organisms, 9 species inhabiting deadwood have rarely been studied. Here we explore the relationships between characteristics of forest stands, deadwood and microclimate, and analyse how the microclimate inside deadwood affects the occurrence of wood-living organisms, exemplified by the red-listed beetle Tragosoma depsarium. Some of the measured deadwood and forest variables explain much of the variation in temperature, but little of humidity aspects of the microclimate within deadwood. Several variables known to influence habitat quality for deadwood-dependent species were found to correlate with microclimate viz.: warmer conditions in standing deadwood and open canopy than in downed logs and under a closed canopy; higher humidity and more stable daily temperatures in shaded habitats and in downed and large-diameter wood, than in sun-exposed locations and standing, small-diameter wood.

T. depsarium occupancy and abundance were negatively correlated with daily temperature fluctuations, and positively related to spring and summer temperature and humidity. This can explain why the species occurred more frequently in deadwood items with characteristics associated with these microclimatic conditions, i.e. downed large-diameter logs occurring in open conditions. Since microclimatic conditions are important for $T$. depsarium and related to several habitat characteristics, we expect the effects of these characteristics to interact with each other, and for species' habitat requirements to vary due to local and regional climate conditions, and to changes due to climate warming.

Keywords: data-logger, habitat, humidity, saproxylic, temperature 
Microclimates, by definition, can vary widely within small geographical areas. This has consequences for species distributions at multiple spatial scales, including their response to climate change (Thomas et al. 1999; Suggitt et al. 2011). Modern low-cost data-loggers have made microclimatic data easier and cheaper to collect in the field (Terando et al. 2017) thus enabling studies to demonstrate the existence of strong links between microclimate and local biodiversity (De Frenne et al. 2021) as well as how microclimate is affected by topography (Gillingham 2010; Seidelmann et al. 2016), vegetation (Ohler et al. 2020), and land-use (Gillingham 2010).

Individual insect species typically flourish with optimal performance (survival, growth, fecundity, and dispersal) within a well-defined temperature range (Chown and Nicolson 2004). Outside the tropics, there is usually a part of the year when the temperature is too low for insect activity (Wolda 1988). Microclimate conditions then become important influences on the development times of insect lifestages and consequently their population dynamics (Johnson et al. 2016; Rebaudo et al. 2016); similarly the spatial distribution of microclimatically suitable habitats affects patterns of occurrence (Sillett et al. 2000).

Approximately one third of all forest insect species are saproxylic, i.e. dependent on dying or dead trees (Ulyshen and Šobotnik 2018). Many of these species are now in decline because forestry practices decrease the amount and quality of deadwood (Siitonen 2001; Stokland et al. 2012); managed forests have far less deadwood than natural forests, especially items of larger dimensions and in later stages of decay (Siitonen 2001; Gossner et al. 2013). Saproxylic species are often specialized on deadwood with certain qualities; wood diameter, canopy openness where the deadwood is situated, tree species from which it is derived, whether standing or downed, and stage of decay are all important characteristics (Siitonen et al. 2000; Stokland et al. 2012; Ranius et al. 2015). Several of these characteristics are likely to influence the microclimatic conditions inside deadwood, but this has never been tested (Müller et al. 2020). 
We hypothesize that the fundamental microclimatic conditions of temperature and humidity inside deadwood are linked to characteristics of both the deadwood items and the surrounding forest and that this in turn can explain the occurrence patterns of saproxylic species. We used the red-listed beetle, Tragosoma depsarium (Linnaeus, 1767), as a study species because field observations indicate that it favours sun-exposed conditions (Wikars 2004; Swedish Species Information Centre 2020). We thus hypothesize that the preferred conditions of $T$. depsarium in its microhabitat of deadwood are largely microclimatic, i.e. that both species' abundance and occurrence patterns as well as habitat characteristics that explain these patterns are strongly correlated with microclimatic variables within. The aim was to answer the following questions:

(i) What are the relationships between the microclimatic conditions in deadwood, and those properties of deadwood and forest characteristics that are known to affect saproxylic insects?

(ii) Which microclimatic variables within deadwood explain the occurrence and abundance of T. depsarium?

(iii) Which deadwood properties and forest characteristics explain the occurrence and abundance of T. depsarium and are they associated with favourable microclimatic conditions within deadwood?

\section{Material and methods}

\section{Study species}

T. depsarium is a $20-35 \mathrm{~mm}$ long saproxylic longhorn beetle. It is a boreo-montane species with fragmented distribution in the mountain regions of southern and central Europe and in boreal forests in eastern Europe and Fennoscandia (Mannerkoski et al. 2010). In Fennoscandia, the larvae develop mainly in large-diameter, bark-free, and sun-exposed logs of Scots pine (Pinus sylvestris), or rarely Norway spruce (Picea abies) (Palm 1951; Wikars 2004), and the development takes four years or more (Palm 1951). When an adult emerges, it creates an easily identifiable exit-hole (Ehnström and Axelsson 2002). It is reported to develop in quite recently dead trees, but also in very old logs which may have 
been dead more than 100 years (Palm 1951). As the species is dependent on deadwood in open habitats, it is threatened by industrial forest management and effective fire-fighting practices, which are causing the forests to become younger and denser, and with less deadwood (Swedish Species Information Centre 2020). The species is classified as Near Threatened (NT) according to European Red List of the IUCN (Nieto and Alexander 2010) and as Vulnerable (VU) according to the Swedish national Red-List (Swedish Species Information Centre 2020).

\section{Study area and design}

We conducted the study in south-eastern Sweden around $20 \mathrm{~km}$ northwest of Uppsala (Fig. 1). The study landscape is around $250 \mathrm{~km}^{2}$ in size and is dominated by coniferous forests (Länsstyrelsen i Uppsala län 2017). It contains large areas dominated by old pine forests that are only partly affected by clear-felling forestry.

We studied the microclimate inside standing (snag) and downed $(l o g)$ deadwood items of pine $(P$. sylvestris) with $T$. depsarium present or absent. The deadwood items studied were identified by using data from a survey conducted in 2015 by Olof Hedgren (Länsstyrelsen i Uppsala län 2017), who reported the coordinates of 62 pine logs with recent exit-holes of the species. We visited the locations of these logs in August and September 2019, searching for fresh exit-holes. New exit-holes are identifiable by their light creamy-white colour, like freshly cut wood; old exit-holes are dark and grey inside (Online Resource 1). New exit-holes were from individuals that had emerged from the deadwood items in 2019 and 2020, while old exit-holes could be of individuals that had emerged many years previously, but not later than 2018. When a deadwood item with a fresh exit-hole was found, a site was identified, defined as the item with a fresh exit-hole together with the three or four closest deadwood items of pine (snag or $l o g$ ), which never occurred farther away than $15 \mathrm{~m}$. Our intention was to include items which potentially varied in their internal microclimatic conditions, but to minimize differences in colonization rate caused by differences in spatial location. We identified 19 such sites. Additionally, we included four sites where the species was absent as control sites, where four or five nearby deadwood 
deadwood items with diameter $\geq 8 \mathrm{~cm}$, because the species rarely uses smaller items (Wikars 2004). In total, 23 sites with 98 deadwood items were included in the study. For each deadwood item, we measured deadwood properties and forest characteristics at the location and counted the number of new and old exit-holes of $T$. depsarium.

We used iButton Hygrochron DS 1923 (Maxim/Dallas Semiconductor Corp., USA) data-loggers to record temperature and humidity inside each deadwood item during the four seasons of a year (from October 2019 to September 2020). The loggers were placed inside deadwood items, on the south-facing side, either close to a new exit-hole or, if new exit-holes were absent, close to the old exit holes or, if no exit-holes were present, in the middle of $\log s$ or $50 \mathrm{~cm}$ above the ground of snags (Fig. 2). In September 2019, we made holes $5 \mathrm{~cm}$ deep and $22 \mathrm{~mm}$ wide, placed loggers inside, and isolated them from the outside air with a wine cork and apple tree wax. Additionally, to measure local air temperature, we placed Lascar EL-USB-1 (Lascar Electronics, UK) temperature data-loggers in the middle of the sites, attaching them on the north side of trees at breast height (1.3 $\mathrm{m}$ from the ground). We used data from October 2019 (autumn), January 2020 (winter), April 2020 (spring) and July 2020 (summer).

The winter temperature in 2020 was considerably higher, at $3.3^{\circ} \mathrm{C}$, than the average temperature during the last 30 years, which was $-2.6 \pm 5.6 \mathrm{SD}^{\circ} \mathrm{C}$, while during other seasons the temperature was closer to the average (autumn 2019: $6.1^{\circ} \mathrm{C}, 30$-year average: $6.1 \pm 4.4 \mathrm{SD}^{\circ} \mathrm{C}$; spring $2020: 5.7^{\circ} \mathrm{C}, 30$-year period: $5.3 \pm 5.2 \mathrm{SD}{ }^{\circ} \mathrm{C}$; summer $2020: 15.5^{\circ} \mathrm{C}$; 30-year period: $17.3 \pm 4.7 \mathrm{SD}{ }^{\circ} \mathrm{C}$; data from the closest weather station; SMHI 2021a).

\section{Deadwood and forest characteristics}

For each deadwood item, we measured characteristics, which have been previously described as important for T. depsarium (Palm 1951; Wikars 2004) or which we assumed could influence microclimate (Online Resource 2). All deadwood variables were measured either within a buffer zone of $2 \mathrm{~m}$ around the new exit-holes, or, if new exit-holes were absent, within a buffer zone of $2 \mathrm{~m}$ around the old exit holes or, if no exit-holes were present, in the middle of the deadwood items. Forest variables were measured while standing above the downed logs and next to the snags. 
133 We recorded whether the deadwood item was standing (snag) or downed on the forest floor $(\log )$.

134 Diameter was measured with a calliper. The length (or height) was measured with a measuring tape if the item was shorter than $2 \mathrm{~m}$, while for longer/higher items it was estimated with $1 \mathrm{~m}$ accuracy. Ground contact, bark cover and vegetation cover of deadwood items were estimated as percentages of how much of the whole deadwood item was in contact with the ground, or covered by bark or vegetation, respectively.

139 For softness, we pressed a knife into the deadwood and measured the blade length that penetrated wood.

140 This was done three times for each item and the average penetration was recorded. Decay stages were 141 classified depending on an item's penetrability according to a published classification system 142 (Larjavaara and Muller-Landau 2010), and placed in one of five classes: 1) recently dead tree: wood still hard, knife blade penetrates a few millimetres, bark normally intact; 2) weakly decayed wood: knife blade penetrates $2 \mathrm{~cm}$, loose bark; 3) medium decayed: knife blade penetrates $2-5 \mathrm{~cm}$, usually without bark; 4) very decayed wood: knife blade penetrates all the way; and 5) almost decomposed wood: breaks up easily by hand, often overgrown by lichens, mosses, and dwarf shrubs.

To estimate canopy openness, photographs were taken with a fisheye lens ca $30-40 \mathrm{~cm}$ above the ground, placing the camera above logs or next to snags. The photos were analysed with a Gap Light Analyzer (Frazer et al. 1999). The variable expresses the percentage of the area not covered by canopy. Basal area - the area $\left(\mathrm{m}^{2}\right)$ of the cross-sections of the tree trunks at breast height $(1.3 \mathrm{~m})$ per hectare, commonly used as an indicator of stand density - was measured with a relascope while standing next to (or above if possible) each deadwood item. The value was estimated for each deadwood item because conditions may differ considerably within a site. The ratio between the chain length and the width of opening of the relascope was $1: 35$, to calculate basal area, the relascope counts were therefore multiplied by two (Järvis 2013). 
The vegetation types were divided into three classes (Wikars 2004): dry (dominated by Vaccinium vitisidaea L. and lichens on the ground); mesic (V. myrtillus L. and pleurocarpous mosses); and wet (Sphagnum-mosses in the bottom layer). However, no deadwood item was located in wet conditions.

160 We divided the sites into four stand types: 1) young clear-cut aged up to around 10 years, or a glade 161 (diameter $>30 \mathrm{~m}$ ), due to a thin soil layer - tree height usually $\leq 3 \mathrm{~m} ; 2$ ) old clear-cut aged around 1124 years - tree height of $3 \mathrm{~m}$ to $15 \mathrm{~m} ; 3$ ) young forest aged around 25-75 years - tree height $>15 \mathrm{~m}$, and average diameter $<20 \mathrm{~cm} ; 4$ ) mature forest aged $>75$ years - tree height $>15 \mathrm{~m}$, and average diameter $>20 \mathrm{~cm}$.

Although topography has been found to be an important factor affecting microclimate (Gillingham 2010; Seidelmann et al. 2016), we did not include that variable in our analyses since our study sites were located in a topographically homogenous landscape with only small differences in average air temperature between the warmest and coldest sites being between $0.8^{\circ} \mathrm{C}$ (in autumn) and $2.7^{\circ} \mathrm{C}$ (in spring and summer).

\section{Statistical analysis}

We used hourly-recorded microclimatic data inside deadwood from October, January, April, and July, to represent autumn, winter, spring, and summer, respectively, from which we calculated mean temperature and humidity, daily temperature fluctuations (as a difference between daily minimum and maximum), minimum temperature of the coldest, and maximum temperature of the warmest month. These microclimatic variables were first analysed in relation to deadwood properties and forest characteristics. To analyse the effect of forest and deadwood characteristics (Online Resource 2) on internal microclimatic variables, we analysed each of the variables described above as response variables in relation to i) deadwood properties; ii) forest characteristics; and iii) deadwood and forest characteristics combined. We used Mixed ANOVA (linear mixed models) and included site as a random factor. Average relative humidity values were transformed with Tukey transformation, analysed with linear models, and back-transformed when presenting the results. 
182 To understand which variables explain the occurrence (presence/absence) and abundance of

183 T. depsarium, we used four data sets: two for occurrence and two for abundance. One of them reflected

184 the current occurrence or abundance, and the second the occurrence or abundance over a longer time

185 span. The current occurrence was obtained by including all examined deadwood items, and considering

186 the presence of new exit-holes. Long-term occurrence was the presence of all exit-holes (new and old)

187 in all examined deadwood items. The current abundance was obtained by including only those

188 deadwood items with new exit-holes present, and assessing the number of new exit-holes. Long-term

189 abundance was obtained by assessing the number of exit-holes excluding the deadwood items with exit-

190 holes absent.

191 We analysed the four response variables of current and long-term occurrence and abundance of

$192 T$. depsarium in relation to deadwood and forest characteristics and microclimatic variables separately

193 and together in order to find out which groups of variables best explain the patterns of T. depsarium.

194 More precisely, we analysed these four response variables in relation to i) deadwood characteristics; ii)

195 forest characteristics; iii) deadwood and forest characteristics combined; iv) internal microclimatic

196 variables (temperature and humidity); v) deadwood and forest characteristics and microclimatic variables combined. Occurrence was analysed using binomial logistic regression with presence (1) or absence (0) as the response variable. Abundance was analysed using a generalized linear model with Poisson distribution. Site was included as a random factor in all models.

Due to the relatively high number of potential predictors $(4 \leq k \leq 24$, depending on the analysis), in all analyses we performed a first selection of the variables, analysing one variable at a time, using secondorder Akaike's information criterion corrected for small sample size (AICc; R package AICcmodavg (Mazerolle 2019)), as recommended when $N$ (sample size) $\times k$ (number of predictors $)^{-1}<40$ (Burnham and Anderson 2002). We selected all variables that decreased the AICc value in comparison to the null model. Thereafter, we built multivariate models by testing all possible combinations of selected variables together, using the R package MuMIn (Barton 2019). For each model, we compared its AICc value with the best-fitting model $\left(\Delta \mathrm{AICc}_{\mathrm{i}}=\mathrm{AICc}_{\mathrm{i}}-\mathrm{AICc}_{\text {min }}\right)$; we considered all plausible models with $\Delta$ AICc $<2$ (Burnham and Anderson 2002), and present them below. Correlated variables (like the 
deadwood variables decay class and softness, and several internal microclimatic variables; $-0.43<r$ or

$210 r>0.43$ ) were never included in the same model.

211 As an absolute value for goodness-of-fit for the models of temperature variables, we report marginal $R^{2}$ 212 (describing the proportion of variance explained by the fixed factor(s) alone) and conditional $R^{2}$ 213 (describing the proportion of variance explained by both the fixed and random factors, i.e. the variance 214 explained by the whole model). For relative humidity, adjusted $R^{2}$ values are presented for models of transformed data. Therefore, these were not included in comparisons with other microclimatic variables. To assess the predictive performance of our models of occurrence and abundance of $T$. depsarium, and to understand which variables are better at explaining the patterns of $T$. depsarium, we used Nagelkerke's pseudo-R-squared $\left(R_{N}^{2}\right)$ and coefficient of determination based on the likelihood-ratio test $\left(R_{L R}^{2}\right)$ values, calculated separately for models with deadwood characteristics, forest characteristics, combination of deadwood and forest characteristics, microclimatic variables, and a combination of all the variables.

\section{Results}

Effect of deadwood and forest characteristics on the internal microclimate of deadwood

In comparison to the local air temperature, it was slightly warmer inside deadwood in autumn $\left(5.7 \pm 0.4 \mathrm{SD}^{\circ} \mathrm{C}\right.$ vs. $\left.5.2 \pm 3.7^{\circ} \mathrm{C}\right)$ and summer $\left(15.9 \pm 1.2^{\circ} \mathrm{C}\right.$ vs. $\left.15.7 \pm 4.9^{\circ} \mathrm{C}\right)$, while it was slightly colder in winter $\left(1.7 \pm 0.6^{\circ} \mathrm{C}\right.$ vs. $\left.2.2 \pm 2.8^{\circ} \mathrm{C}\right)$ and spring $\left(6.0 \pm 1.2^{\circ} \mathrm{C}\right.$ vs. $\left.6.1 \pm 5.8^{\circ} \mathrm{C}\right)$. The daily temperature fluctuations were always lower inside wood compared to the air (autumn: $3.2 \pm 0.9{ }^{\circ} \mathrm{C}$ vs. $5.7 \pm 3.0^{\circ} \mathrm{C}$; winter: $1.7 \pm 0.7^{\circ} \mathrm{C}$ vs. $4.0 \pm 2.3^{\circ} \mathrm{C}$; spring: $8.4 \pm 2.7^{\circ} \mathrm{C}$ vs. $12.4 \pm 6.5^{\circ} \mathrm{C}$; summer: $8.3 \pm 3.0^{\circ} \mathrm{C}$ vs. $\left.10.7 \pm 6.3^{\circ} \mathrm{C}\right)$.

Deadwood and forest characteristics combined explained a considerable part of the average temperature $\left(0.33 \leq R^{2}{ }_{c} \leq 0.72\right)$, temperature fluctuations $\quad\left(0.34 \leq R^{2}{ }_{c} \leq 0.56\right)$, and temperature extremes $\left(0.41 \leq R_{c}^{2} \leq 0.46\right.$; Table 1; Online Resource 3). In autumn and winter, deadwood characteristics explained average temperature and temperature fluctuations better than forest characteristics (Online Resource 4). By contrast, forest characteristics were better at explaining all temperature variables in 
summer, and temperature fluctuations in spring (Online Resource 5). Average humidity was poorly explained $\left(-0.02 \leq R^{2}\right.$ adj $\left.\leq 0.14\right)$ by deadwood and forest characteristics (Table 2$)$.

Five deadwood characteristics (especially log, but also diameter, length, vegetation cover, and decay stage/softness) and three forest characteristics (especially canopy openness, but also basal area, and vegetation type) occurred frequently in the models predicting climate variables (Tables 1 and 2). In comparison to $\log s$, the average temperature was higher in snags (snags: autumn $5.9 \pm 0.5 \mathrm{SD}^{\circ} \mathrm{C}$; winter $2.0 \pm 0.6^{\circ} \mathrm{C}$; $\log s$ autumn $5.6 \pm 0.4{ }^{\circ} \mathrm{C}$; winter $1.5 \pm 0.5^{\circ} \mathrm{C}$ ), the daily temperature fluctuations were wider (Online Resource 6), the summer maximum temperature higher (snags: $20.5 \pm 2.8^{\circ} \mathrm{C}$; logs: $20.3 \pm 2.6^{\circ} \mathrm{C}$ ) and the humidity lower (snags autumn $97.2 \pm 7.5 \mathrm{SD} \%$; summer $88.4 \pm 15.1 \%$; $\operatorname{logs}$ autumn $101.5 \pm 8.3 \%$; summer $98.5 \pm 23.8 \%$ ). In deadwood items with larger diameters, daily temperature fluctuations were lower, but winter minimum temperatures (Table 1) and humidities were higher (Table 2). Deadwood items that were longer and with higher vegetation cover had higher humidity. In later decay stages, the daily temperature fluctuations were narrower, while with increased softness the humidity was higher.

Average temperature (Fig. 3), daily temperature fluctuation, and summer maximum temperature increased with increasing canopy openness, while humidity decreased (Tables 1 and 2). The average and minimum temperatures in winter increased with higher basal area. Average temperature was higher in dry (autumn $5.8 \pm 0.5 \mathrm{SD}^{\circ} \mathrm{C}$, summer $16.3 \pm 1.3^{\circ} \mathrm{C}$ ) than in mesic vegetation type (autumn $5.6 \pm 0.3{ }^{\circ} \mathrm{C}$, summer $15.5 \pm 0.9^{\circ} \mathrm{C}$ ), but daily temperature fluctuations (in spring, in dry $8.7 \pm 3.0^{\circ} \mathrm{C}$ versus in mesic $8.0 \pm 2.4^{\circ} \mathrm{C}$ ) and humidity were lower in dry vegetation type (in spring, in dry $93.5 \pm 24.2 \mathrm{SD} \%$ versus in mesic $98.8 \pm 14.9 \%)$.

\section{Occurrence and abundance of T. depsarium}

We observed 472 exit-holes of $T$. depsarium. Among these, 100 exit-holes were new, distributed among 28 logs, while the 372 old exit-holes were distributed among 40 logs. The species inhabited only downed logs and never snags. 
261 The combination of deadwood and forest characteristics and microclimatic variables was almost always

262 better $\left(0.71 \leq R_{N}^{2} \leq 0.99\right)$ at explaining occurrence and abundance of $T$. depsarium (Fig. 4) than only 263 deadwood characteristics $\left(0.34 \leq R^{2}{ }_{N} \leq 0.65\right.$; Online Resource 7), only forest characteristics $264\left(0.17 \leq R^{2}{ }_{N} \leq 0.72 ; \quad\right.$ Online Resource 8), deadwood and forest characteristics combined $265\left(0.43 \leq R^{2} \leq 0.89\right.$; Table 3$)$, or only microclimatic variables $\left(0.63 \leq R^{2}{ }_{N} \leq 0.99\right.$; Table 4$)$. The combination of deadwood and forest characteristics $\left(0.70 \leq R^{2}{ }_{N} \leq 0.78\right)$ explained occurrence equally well as microclimatic variables $\left(0.62 \leq R^{2} \leq 0.70\right)$, but microclimatic variables were better at explaining abundance of $T$. depsarium $\left(0.82 \leq R^{2}{ }_{N} \leq 0.99\right)$ than the combination of deadwood and forest characteristics $\left(0.37 \leq R^{2}{ }_{N} \leq 0.89\right)$.

In comparison to unoccupied deadwood items, occupied items had larger diameter (current: $26.7 \pm 4.4$ SD cm vs. $22.3 \pm 8.3 \mathrm{~cm}$; long-term: $26.5 \pm 6.4 \mathrm{~cm}$ vs. $22.2 \pm 8.2 \mathrm{~cm}$ ), and were situated in stands with smaller basal area (current: $6.4 \pm 4.7 \mathrm{SD} \mathrm{m}^{2} \mathrm{ha}^{-1}$ vs. $16.9 \pm 10.3 \mathrm{~m}^{2}$ ha $^{-1}$; long-term: $6.9 \pm 4.7 \mathrm{~m}^{2}$ ha $^{-1}$ vs. $16.6 \pm 10.4 \mathrm{~m}^{2}$ ha $^{-1}$; Table 3 ). Currently occupied logs were longer $(1460 \pm 593 \mathrm{SD} \mathrm{cm}$ vs. $850 \pm 684 \mathrm{~cm})$, and long-term occupancy was higher in items of later decay stages.

The average temperatures in currently occupied deadwood items were slightly lower in autumn $\left(5.6 \pm 0.4 \mathrm{SD}^{\circ} \mathrm{C}\right.$ vs. $\left.5.7 \pm 0.5^{\circ} \mathrm{C}\right)$, fluctuated less in winter $\left(1.2 \pm 0.5^{\circ} \mathrm{C}\right.$ vs. $\left.1.9 \pm 0.7^{\circ} \mathrm{C}\right)$ and had higher summer maximum $\left(20.9 \pm 2.5^{\circ} \mathrm{C}\right.$ vs. $20.1 \pm 2.6^{\circ} \mathrm{C}$; Table 4$)$. In comparison to unoccupied deadwood items, in long-term occupied items, the average temperatures were slightly higher in spring $\left(6.2 \pm 1.4{ }^{\circ} \mathrm{C}\right.$ vs. $\left.5.8 \pm 1.0^{\circ} \mathrm{C}\right)$, and the humidities were lower in winter ( $88.3 \pm 23.5 \mathrm{SD} \%$ vs. $\left.90.2 \pm 20.0 \%\right)$ and summer $(92.0 \pm 27.9 \%$ vs. $100.9 \pm 12.7 \%)$.

Current $T$. depsarium were more abundant in $\log s$ with lower average and maximum temperatures in the summer, and with a narrower range of temperature fluctuations in autumn. Furthermore, abundance increased with higher average humidities in winter, spring, and summer. The long-term abundance increased with higher average temperature in spring and humidity in winter, and lower humidity in autumn (Table 4). 


\section{Discussion}

288 During the last two decades, a large number of studies have revealed that different deadwood and forest characteristics (wood diameter, canopy openness, whether standing or downed, and decay stage) affect occurrence patterns of saproxylic species (Siitonen et al. 2000; Stokland et al. 2012; Ranius et al. 2015). We have shown for the first time that these deadwood characteristics are driving microclimatic conditions inside deadwood. Furthermore, we have shown that deadwood and forest characteristics combined, explain the occurrence of $T$. depsarium as well as microclimatic variables, while the abundance of the species is explained better by microclimatic variables than deadwood and forest characteristics. This supports the view that the species is directly affected by the microclimatic conditions in deadwood.

\section{Importance of deadwood and forest characteristics for microclimate}

The microclimate inside deadwood was affected by both deadwood and forest characteristics. The most important factors affecting microclimate in deadwood items in the present study (Table 1) have all been found to be important for species inhabiting deadwood: habitat openness (canopy openness and basal area) (Müller et al. 2015; Seibold et al. 2016), whether the item is standing or downed, and the dimension of the item (diameter: Siitonen et al. 2000; Ranius et al. 2015; and length: Haeler et al. 2021).

During the warmer part of the year, a higher degree of canopy openness implied higher average and maximum temperature as well as larger daily fluctuations, and lower humidity. In contrast, during winter time it was warmer where the basal area was higher. This is similar to observations of nearground microclimate (Greiser et al. 2018), and can be explained by the fact that the canopy has a buffering effect on temperature (De Frenne et al. 2019) by reducing incoming solar radiation during the day and heat loss overnight (Geiger et al. 2012; Gaudio et al. 2017). Additionally, the deadwood was drier with increasing canopy openness. This can be due to both higher temperatures and increased wind speed (Renaud et al. 2011).

311 The average temperature was higher and fluctuated more in snags than in logs and they were also drier. 
313 often covering the downed log protects them from direct sunlight (Talley et al. 2002; Bässler et al.

314 2010). Higher water content, in turn, tends to give more stable temperatures. The microclimatic

315 differences may affect organisms both directly, but also indirectly by, for instance, affecting the rate of

316 decay of deadwood (Eichenberg et al. 2017).

317 Larger deadwood items - principally with a higher diameter, but to some extent also greater length -

318 had more stable temperatures, higher winter minimum temperature and higher humidity. The higher

319 moisture could be explained by a larger volume in relation to the surface area, and hence lower

320 evaporation. The more stable temperatures could be due to the wood buffering temperature changes

321 (Walczyńska and Kapusta 2017); higher humidity also contributes to the decrease of temperature

fluctuations. The more stable microclimatic conditions could be one reason why many wood-living species prefer deadwood of larger dimensions, although, inter alia, large diameter deadwood also persists longer (Hyvönen et al. 2000).

The decomposition stage of the deadwood items explained part of the microclimatic variability; the daily temperature fluctuation decreased with decay stage in spring, while humidity increased with softness in autumn. Pouska et al. (2016) also found that as the state of decay progressed the water content of the wood and its temperature stability increased. This may be because the water holding capacity of wood increases as it decays (Harmon and Sexton 1995) and higher humidity buffers temperature fluctuations (Davis et al. 2019).

The difference in average temperature between the warmest and coldest deadwood items was between $2.2^{\circ} \mathrm{C}$ (in autumn) and $5.7^{\circ} \mathrm{C}$ (in summer). This is comparable with the predicted effect of climate warming in Uppsala (where this study was done), which is between $2.3{ }^{\circ} \mathrm{C}$ and $4.4{ }^{\circ} \mathrm{C}$ in the next 40 years according to an ensemble of nine climate scenarios based on RCP8.5, a scenario with emissions considerably higher than those laid down under the current Paris agreement (SMHI 2021b). It is also comparable with temperature differences between southernmost (Sturup, latitude 55.52) and northernmost (Latnivaara, latitude 67.25) parts of Sweden, a distance of about $1750 \mathrm{~km}$, over which the difference in annual average temperature has been $9.6^{\circ} \mathrm{C}$ over the last 30 years (SMHI 2021a). Thus, 
the observed difference between deadwood items corresponds to differences between sites situated 400-

$3401000 \mathrm{~km}$ from each other in a south-north direction. This implies that in a topographically homogenous

341 area, deadwood and forest characteristics have a lesser effect on the microclimate inside deadwood than

342 climatic differences might have over north-south distances exceeding $1000 \mathrm{~km}$, and be of the same

343 magnitude as that predicted under climate warming during an intermediate time scale. Thus, species are

344 probably able to compensate for less favourable regional climatic conditions and changes over time by

345 using different types of deadwood. However, the variation between northern and southern Sweden is

346 too large for $T$. depsarium to compensate for it by selecting different types of deadwood. Indeed, $T$.

347 depsarium is absent from the coldest, northwestern part of Sweden (Swedish Species Information

348 Centre 2020), probably because it is too cold.

\section{Occurrence and abundance of T. depsarium}

350 Microclimatic variables were as good as the deadwood and forest characteristics combined at explaining 351 the occurrence of T. depsarium, but better at explaining their abundance. The strong relationship between microclimatic variables and the occurrence and abundance of the species is consistent with several field studies on insects in other habitats showing a similarly strong effect of microclimate on occurrence and abundance (e.g. Eilers et al. 2013; Righi et al. 2018), but this has until now not been documented for any saproxylic insects in deadwood.

T. depsarium occurred more often and at higher abundance in deadwood items with narrow temperature fluctuations and high average temperatures in spring, and, to some extent, with high summer temperatures, and cooler temperatures during winter and autumn. Higher humidity in spring and summer was also favourable for the species. High temperatures and narrow temperature fluctuations are also important for other species, e.g., a moth (Moore et al. 2021), and higher humidity for, e.g., dung beetles (Righi et al. 2018). The microclimatic preferences we observed agree with the habitat requirements of $T$. depsarium reported elsewhere (Palm 1951; Wikars 2004). In our study we also found the species to occur more often and more abundantly where the canopy was more open, where the spring and summer temperatures were higher; they were also more abundant in well-decayed wood, and where 
the temperature fluctuations in spring were narrow. The negative relationship with autumn and winter temperatures was unexpected, but an explanation could be that with decreasing autumn and winter temperatures, daily temperature fluctuations during these seasons decreased, and average temperature during spring and maximum in summer increased. Greiser et al. (2018) have observed similar seasonal patterns. Especially if the relationships are non-linear, autumn and winter climate may be included in the models, even if their direct effect on insects are only weak or even absent.

Although microclimate is clearly important, other factors undoubtedly affect the species. For example, the state of decaying wood for saproxylic beetles (Müller et al. 2020), such as T. depsarium affects the availability of nutrients (Laiho and Prescott 2004). Furthermore, since T. depsarium has a development time of around four years (Palm 1951), our data, based on emergence holes, might also explain why we rarely found the species in wood in its earliest stages of decay. The higher frequency of occurrence and abundance in larger logs could, except of more narrow temperature fluctuations, also be explained by more resources available.

\section{Implications for conservation}

We have shown a correlation between internal microclimatic conditions in deadwood and the occurrence patterns of $T$. depsarium. This has consequences for our understanding of the habitat requirements of saproxylic species. First, the microclimatic conditions within deadwood are affected by a hierarchy of interacting influences. These range from certain properties of the deadwood itself; characteristics of the forest from which it is derived; and by regional and local climatic conditions, which in turn are affected by, e.g. topography and distance to water bodies (De Frenne et al. 2021). The microclimatic conditions within deadwood are the results of all these factors interacting, and thus, we should expect species to live in different types of deadwood in different parts of their distribution areas. Second, we should expect that climate change will have a large impact on saproxylic organisms. They may not only change their distribution areas, but they could also remain within their current areas by using different types of deadwood, with different microclimatic conditions. 
391 Forestry has a large effect on saproxylic insects, since it decreases the amount and quality of deadwood

392 (Stokland et al. 2012). Our study indicates that other consequences of forestry may also be important.

393 Intensive forest management generates both more dense forests (Swedish Species Information Centre

394 2020) and, after clear-cutting, very sun-exposed conditions. These dynamic changes affect

395 microclimatic conditions (Greiser 2020), which in turn affect saproxylic species. Thus, modifying

396 forestry practices could mitigate some of the negative consequences of climate change on saproxylic

397 insects.

398

399 Acknowledgements

400 We are grateful to Olof Hedgren, who undertook the survey that provided information concerning the

401 presence of Tragosoma depsarium. We thank R. Francis, E. Freyhult and J. Lorent for statistical advice.

402

403 Declarations

404 Funding Carl Tryggers Foundation and Stiftelsen fonden för skogsvetenskaplig forskning.

405 Conflicts of interest/Competing interests The authors declare that they have no conflict of interest.

406 Ethics approval All applicable national guidelines for the care and use of animals were followed.

407 Consent to participate Not applicable.

408 Consent for publication Not applicable.

409 Availability of data and material Available from the corresponding author on reasonable request.

410 Code availability Available from the corresponding author on reasonable request.

411 Authors' contributions TR originally formulated the idea. All co-authors developed and planned the

412 project. LL conducted the field work and analysed the data. LL wrote the first draft of the manuscript

413 with active support from TR, and all co-authors contributed to the final version of the manuscript.

414

$415 \quad$ References

416 Bartoń K (2019) MuMIn: multi-model inference. R package version 1.43.15. The Comprehensive R

417 Archive Network (CRAN), Vienna 
Bässler C, Müller J, Dziock F, Brandl R (2010) Effects of resource availability and climate on the

419 diversity of wood-decaying fungi. Journal of Ecology 98: 822-832, doi: 10.1111/j.1365$420 \quad 2745.2010 .01669 . x$

421 Burnham KP, Anderson DR (2002) Model selection and multimodel inference: a practical informationtheoretic approach, 2nd edn. Springer, New York

Chown SL, Nicolson SW (2004) Insect Physiological Ecology: Mechanisms and Patterns. Oxford University Press, Oxford

Davis KT, Dobrowski SZ, Holden ZA, Higuera PE, Abatzoglou JT (2019) Microclimatic buffering in forests of the future: the role of local water balance. Ecography 42: 1-11, doi: 10.1111/ecog.03836

De Frenne P, Lenoir J, Luoto M, Scheffers BR, Zellweger F, Aalto J, ... Hylander K (2021) Forest microclimates and climate change: Importance, drivers and future research agenda. Global Change Biology 00: 1-19, doi: 10.1111/gcb.15569

De Frenne P, Zellweger F, Rodríguez-Sánchez F, Scheffers B, Hylander K, Luoto M, ... Lenoir J (2019) Global buffering of temperatures under forest canopies. Nature Ecology \& Evolution 3: 744-749, doi: $10.1038 / \mathrm{s} 41559-019-0842-1$

Ehnström B, Axelsson R (2002) Insect marks in bark and wood. ArtDatabanken, Uppsala, in Swedish with English summary

Eichenberg D, Pietsch K, Meister C, Ding W, Yu M, Wirth C (2017) The effect of microclimate on wood decay is indirectly altered by tree species diversity in a litterbag study. Journal of Plant Ecology 10: 170-178, doi: 10.1093/jpe/rtw116

Eilers S, Pettersson LB, Öckinger E (2013) Micro-climate determines oviposition site selection and abundance in the butterfly Pyrgus armoricanus at its northern range margin. Ecological Entomology 38: 183-192, doi: 10.1111/een.12008

441 Frazer GW, Canham CD, Lertzman KP (1999) Gap Light Analyzer (GLA), Version 2.0: Imaging software to extract canopy structure and gap light transmission indices from true-colour fisheye photographs, users manual and program documentation. Simon Fraser University, Burnaby, British Columbia, and the Institute of Ecosystem Studies, Millbrook, New York. 
Gaudio N, Gendre X, Saudreau M, Seigner V, Balandier P (2017) Impact of tree canopy on thermal and

446 radiative microclimates in a mixed temperate forest: A new statistical method to analyse hourly

447 temporal dynamics. Agricultural and Forest Meteorology 237-238: 71-79, doi:

$448 \quad$ 10.1016/j.agrformet.2017.02.010

449 Geiger R, Aron RH, Todhunter P (2012) The climate near the ground. $5^{\text {th }}$ edition. Springer Science \&

450 Business Media

451 Gillingham P (2010) The relative importance of microclimate and land use to biodiversity. PhD thesis,

452 University of York. URL: http://etheses.whiterose.ac.uk/1210/

453 Gossner MM, Lachat T, Brunet J, Isacsson G, Bouget C, Brustel H, Brandl R, Weisser W, Müller J

454 (2013) Current near-to-nature forest management effects on functional trait composition of saproxylic

455 beetles in beech forests. Conservation Biology 27: 605-614, doi: 10.1111/cobi.12023

456 Greiser C (2020) Microclimate at range margins: Consequences for boreal forest understory species.

$457 \mathrm{PhD}$ thesis. Stockholm University, Department of Ecology, Environment and Plant Sciences

458 Greiser C, Meineri E, Luoto M, Ehrlén J, Hylander K (2018) Monthly microclimate models in a 459 managed boreal forest landscape. Agricultural and Forest Meteorology 250-251: 147-158, doi: $460 \quad$ 10.1016/j.agrformet.2017.12.252

461 Haeler E, Bergamini A, Blaser S, Ginzler C, Hindenlang K, Keller C, Kiebacher T, Kormann UG, 462 Scheidegger C, Schmidt R, Stillhard J, Szallies A, Pellissier L, Lachat T (2021) Saproxylic species are linked to the amount and isolation of dead wood across spatial scales in a beech forest. Landscape Ecology 36: 89-104, doi: 10.1007/s10980-020-01115-4(0123456789().,-volV)( 01234567

Hyvönen R, Olsson BA, Lundkvist H, Staaf H (2000) Decomposition and nutrient release for Picea abies (L.) Karst. and Pinus sylvestris L. logging residues. Forest Ecology and Management 126: 97112, doi: 10.1016/S0378-1127(99)00092-4 Järvis J (2013) Forest measurement with relascope. Practical description for fieldwork with examples

URL:

470 https://dspace.emu.ee/xmlui/bitstream/handle/10492/4607/Relascope_en_2013.pdf?sequence=1\&isAll owed=y, accessed in December 2020 

P (2016) Effects of temperature and resource variation on insect population dynamics: the bordered plant bug as a case study. Functional Ecology 30: 1122-1131, doi: 10.1111/1365-2435.12583

Larjavaara M, Muller-Landaru HC (2010) Comparison of decay classification, knife test, and two penetrometers for estimating wood density of coarse woody debris. Canadian Journal of Forest Research 40: 2313-2321, doi: 10.1139/X10-170

Länsstyrelsen i Uppsala län (2017) Raggbocken i Ulleråkerstrakten - ett samarbete kring åtgärder för tallberoende arters överlevnad. Länsstyrelsens meddelandeserie, 42 pp.

Moore EM, Hill CA, Kingsolver JG (2021) Differing thermal sensitivities in a host-parasitoid interaction: High, fluctuating developmental temperatures produce dead wasps and giant caterpillars. Functional Ecology 35: 675-685, doi: 10.1111/1365-2435.13748

R, Mico E, Méndez M (2010) Tragosoma depsarium. The IUCN Red List of Threatened Species 2010: e.T157922A5174376. Accessed in May 2021 Mazerolle MJ (2019) AICcmodavg: model selection and multimodel inference based on (Q) AIC(c). R package version 2.2-2. The Comprehensive R Archive Network (CRAN), Vienna Müller J, Ulyshen M, Seibold S, Cadotte M, Chao A, Bässler C, Vogel S, Hagge J, Weiß I, Baldrian P, Tláskal V, Thorn S (2020) Primary determinants of communities in deadwood vary among taxa but are regionally consistent. Oikos 129: 1579-1588, doi: 10.1111/oik.07335 Müller J, Brustel H, Brin A, Bussler H, Bouget C, Obermaier E, Heidinger IMM, Lachat T, Förster B, Increasing temperature may compensate for lower amounts of dead wood in driving richness of saproxylic beetles. Ecography 38: 499-509, doi: 10.1111/ecog.00908 Office of the European Union Ohler LM, Lechleitner M, Junker RR (2020) Microclimatic effects on alpine plant communities and flower-visitor interactions. Scientific Reports 10: 1366, doi: 10.1038/s41598-020-58388-7 
499 Palm T (1951) Die Holz- und Rinden-Käfer der süd- und mittelschwedischen Laubbäume. Opuscula

500 Entomologica: Supplementum 16: 1-374

501 Pouska V, Macek P, Zíbarová L (2016) The relation of fungal communities to wood microclimate in a 502 mountain spruce forest. Fungal Ecology 21: 1-9, doi: 10.1016/j.funeco.2016.01.006

503 Ranius T, Johansson V, Schroeder M, Caruso A (2015) Relative importance of habitat characteristics 504 at multiple spatial scales for wood-dependent beetles in boreal forest. Landscape Ecology 30: 19311942, doi: 10.1007/s10980-015-0221-5

506 Rebaudo F, Faye E, Dangles O (2016) Microclimate data improve predictions of insect abundance 507 models based on calibrated spatiotemporal temperatures. Frontiers in Physiology 7: 139, doi: 10.3389/fphys.2016.00139

Renaud V, Innes JL, Dobbertin M, Rebetez M (2011) Comparison between open-site and below-canopy climatic conditions in Switzerland for different types of forests over 10 years (1998-2007). Theoretical and Applied Climatology 105: 119-127, doi: 10.1007/s00704-010-0361-0

512 Righi CA, Sandoval Rodríguez C, Ferreira ENL, Godoy WAC, Cognato AI (2018) Microclimatic 513 conditions for dung beetle (Coleoptera: Scarabaeidae) occurrence: land use system as a determining 514 factor. Environmental Entomology 47: 1420-1430, doi: 10.1093/ee/nvy163

515 Seibold S, Bässler C, Brandl R, Büche B, Szallies A, Thorn S, Ulyshen MD, Müller J (2016) 516 Microclimate and habitat heterogeneity as the major drivers of beetle diversity in dead wood. Journal 517 of Applied Ecology 53: 934-943, doi: 10.1111/1365-2664.12607

518 Seidelmann KN, Scherer-Lorenzen M, Niklaus PA (2016) Direct vs. microclimate-driven effects of tree 519 species diversity on litter decomposition in young subtropical forest stands. PLoS ONE 11(8): e0160569, doi: 10.1371/journal.pone.0160569

521 Siitonen J (2001) Forest management, coarse woody debris and saproxylic organisms: Fennoscandian boreal forests as an example. Ecolgical Bulletins 49: 11-42, doi: 10.2307/20113262 Siitonen J, Martikainen P, Punttila P, Rauh J (2000) Coarse woody debris and stand characteristics in mature managed and old-growth boreal mesic forests in southern Finland. Forest Ecology and Management 128: 211-225, doi: 10.1016/S0378-1127(99)00148-6 
Sillett TS, Holmes RT, Sherry TW (2000) Impacts of a global climate cycle on population dynamics of a migratory songbird. Science 288: 2040-2042, doi: 10.1126/science.288.5473.2040 SMHI (2021a) Historical data. URL: https://www.smhi.se/data/meteorologi/ladda-ner-meteorologiskaobservationer/\#param=airtemperatureInstant,stations=all,stationid=97530, accessed in April 2021 SMHI (2021b) Climate scenarios. URL: https://www.smhi.se/en/climate/future-climate/climatescenarios/sweden/county/uppsala/rcp85/year/temperature, accessed in May 2021

Stokland JN, Siitonen J, Jonsson BG (2012) Biodiversity in dead-wood. Cambridge University Press, New York

Suggitt A J, Gillingham PK, Hill JK, Huntley B, Kunin WE, Roy DB, Thomas CD (2011) Habitat microclimates drive fine-scale variation in extreme temperatures. Oikos 120: 1-8, doi: 10.1111/j.16000706.2010.18270.x

Swedish Species Information Centre (2020) Red list 2020: Tragosoma depsarium. URL: https://artfakta.se/naturvard/taxon/tragosoma-depsarium-101920, accessed in January 2021 Talley SM, Coley PD, Kursar TA (2002) The effects of weather on fungal abundance and richness among 25 communities in the Intermountain West. BMC Ecology 2: 7-10, doi: 10.1186/1472-6785-27

542 Terando AJ, Youngsteadt E, Meineke EK, Prado SG (2017) Ad hoc instrumentation methods in ecological studies produce highly biased temperature measurements. Ecology and Evolution 7: 98909904, doi: 10.1002/ece3.3499

Thomas JA, Rose RJ, Clarke RT, Thomas CD, Webb NR (1999) Intraspecific variation in habitat

546 availability among ectothermic animals near their climatic limits and their centres of range. Functional

547 Ecology 13: 55-64, doi: 10.1046/j.1365-2435.1999.00008.x

548 Ulyshen M, Šobotnik J (2018) An introduction to the diversity, ecology and conservation of saproxylic 549 insects. Zoological Monographs 1: 1-47, doi: 10.1007/978-3-319-75937-1_1

550 Walczyńska A, Kapusta P (2017) Microclimate buffering of winter temperatures by pine stumps in a temperate forest. Climate Dynamics 48: 1953-1961, doi: 10.1007/s00382-016-3184-6 
552 Wikars L-O (2004) Habitat requirements of the pine wood-living beetle Tragosoma depsarium 553 (Coleoptera: Cerambycidae) at log, stand, and landscape scale. Ecological Bullentins 51: 287-294, doi: $554 \quad 130.238 .111 .87$

555 Wolda H (1988) Insect Seasonality: Why? Annual Review of Ecology and Systematics 19: 1-18. URL: 556 http://www.jstor.org/stable/2097145, accessed in April 2021 
Table 1. Plausible candidate models ( $\triangle \mathrm{AICc}<2)$ explaining (1) average temperature; (2) temperature fluctuations in (a) autumn, (b) winter, (c) spring, and (d) summer; (3) temperature extremes in (a) winter and (b) summer, in relation to deadwood and forest characteristics. Site as a random factor is included in all models. Sample size (N), intercept (Int.), number of parameters $(\mathrm{k})$, model weight $\left(\mathrm{w}_{i}\right)$, marginal $R^{2}\left(R_{m}^{2}\right)$ and conditional $R^{2}\left(R_{c}^{2}\right)$ are presented

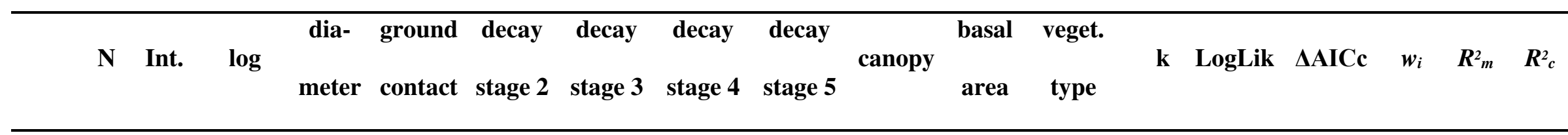

\section{Average temperature}

a) in autumn

$$
\begin{array}{lll}
77 & 5.93 & -0.350 \\
& 6.01 & -0.343
\end{array}
$$

b) in winter

$$
\begin{array}{lll}
78 & 1.43 & -0.408
\end{array}
$$

c) in spring

$$
77 \quad 4.55
$$

d) in summer

$$
77 \quad 13.44
$$

\section{Temperature fluctuations}

$-0.288$

$4 \quad-106.62$

0.00


a) in autumn

$$
\begin{array}{llll}
76 & 2.75 & & -0.049 \\
& & & \\
& 3.08 & -0.300 & -0.054
\end{array}
$$

b) in winter

$$
\begin{array}{lllll}
78 & 3.06 & -0.390 & -0.032 & -0.009
\end{array}
$$

c) in spring

$$
\begin{array}{lll}
77 & 4.27 & \\
& & \\
& 3.71 & \\
& & \\
& 4.17 & -0.214
\end{array}
$$

d) in summer

$$
\begin{array}{lll}
77 & 2.44 & \\
& & \\
& 2.12 & 0.423 \\
& & \\
& & \\
& &
\end{array}
$$

$\begin{array}{lllll}0.037 & 0.085 & -0.210 & -1.897 & 0.080 \\ -0.093 & 0.091 & -0.033 & -1.869 & 0.085 \\ -0.078 & -0.035 & -0.336 & -1.977 & 0.080\end{array}$

0.104

0.104

0.105

$\begin{array}{llllll}5 & -91.71 & 0.00 & 0.66 & 0.39 & 0.43 \\ 6 & -91.21 & 1.36 & 0.34 & 0.41 & 0.48\end{array}$

$\begin{array}{llllll}6 & -68.28 & 0.00 & 1.00 & 0.35 & 0.56\end{array}$

$\begin{array}{lllllll} & 8 & 356.5 & 0.00 & 0.47 & 0.34 & 0.53 \\ 0.584 & 9 & 357.3 & 0.81 & 0.31 & 0.40 & 0.46 \\ & 9 & 358.0 & 1.54 & 0.22 & 0.39 & 0.52\end{array}$

$\begin{array}{llllll}4 & -183.57 & 0.00 & 0.46 & 0.33 & 0.34\end{array}$

$\begin{array}{llllll}5 & -182.87 & 0.89 & 0.30 & 0.33 & 0.34\end{array}$

$\begin{array}{lllllll}0.066 & 5 & -183.07 & 1.30 & 0.24 & 0.32 & 0.35\end{array}$

\section{Temperature extremes}

a) $\min$ in winter

$\begin{array}{ccc}78 & -0.03 & 0.020 \\ & 0.50 & \end{array}$

0.061

$\begin{array}{llllll}5 & -40.90 & 0.00 & 0.62 & 0.42 & 0.46\end{array}$

0.055

$\begin{array}{llllll}4 & -42.52 & 0.96 & 0.38 & 0.31 & 0.41\end{array}$ 
b) max in summer

14.57

0.101

$\begin{array}{llllll}4 & -164.73 & 0.00 & 0.53 & 0.43 & 0.43\end{array}$

14.87

0.098

$-0.302$

$5 \quad-164.33$

1.50

$\begin{array}{lll}0.25 & 0.43 & 0.43\end{array}$

$14.60-0.042$

0.101

$5 \quad-164.49$

$\begin{array}{llll}1.80 & 0.22 & 0.43 & 0.43\end{array}$ 
Table 2. Plausible candidate models ( $\triangle \mathrm{AICc}<2)$ explaining average humidity in (a) autumn, (b) winter, (c) spring, and (d) summer in relation to deadwood

\begin{tabular}{|c|c|c|c|c|c|c|c|c|c|c|c|c|c|c|c|}
\hline $\mathbf{N}$ & Int. & $\log$ & $\begin{array}{l}\text { dia- } \\
\text { meter }\end{array}$ & length & $\begin{array}{c}\text { ground } \\
\text { cont. }\end{array}$ & bark & $\begin{array}{l}\text { veget. } \\
\text { cover }\end{array}$ & $\begin{array}{l}\text { soft- } \\
\text { ness }\end{array}$ & canopy & $\begin{array}{c}\text { veget. } \\
\text { type }\end{array}$ & $\mathbf{k}$ & LogLik & $\triangle \mathrm{AICc}$ & $w_{i}$ & $\boldsymbol{R}_{a d j}^{2}$ \\
\hline \multicolumn{16}{|c|}{ a) in autumn } \\
\hline 76 & 99.10 & 88.06 & & & & & 51.44 & 64.99 & -49.88 & & 6 & -2946.30 & 0.00 & 0.40 & 0.14 \\
\hline & 99.85 & 87.48 & & & & & & 66.49 & -50.31 & & 5 & -2947.59 & 0.23 & 0.35 & 0.12 \\
\hline & 128.97 & 89.05 & 56.22 & & & & 50.85 & 63.39 & -49.84 & & 7 & -2945.53 & 0.90 & 0.25 & 0.15 \\
\hline
\end{tabular}

b) in winter

78104.33

$101.43 \quad 60.84$

103.08

104.71

104.26

c) in spring

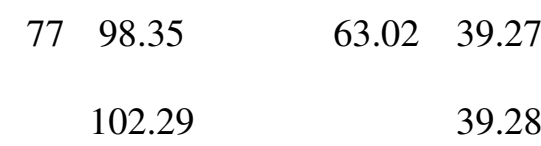

39.28
$-48.20$

$-48.70$

$-45.74$

$-47.15$
49.49

$-47.94$
$3 \quad-3160.66 \quad 0.00 \quad 0.33 \quad-0.01$

$\begin{array}{lllll}4 & -3159.90 & 0.70 & 0.24 & -0.01\end{array}$

$\begin{array}{lllll}4 & -3160.28 & 1.45 & 0.16 & -0.02\end{array}$

$\begin{array}{lllll}4 & -3160.42 & 1.74 & 0.14 & -0.02\end{array}$

$\begin{array}{lllll}4 & -3160.46 & 1.82 & 0.13 & -0.02\end{array}$

$\begin{array}{llllll}-55.09 & 5 & -3263.62 & 0.00 & 0.36 & 0.08 \\ -54.83 & 4 & -3265.02 & 0.50 & 0.28 & 0.05\end{array}$




$\begin{array}{lllllllllll}97.89 & 62.08 & 39.62 & 54.06 & -54.90 & & 6 & -3263.04 & 1.19 & 0.20 & 0.08 \\ 96.39 & 63.18 & 39.21 & & -52.91 & 80.30 & 6 & -3263.21 & 1.53 & 0.16 & 0.07\end{array}$

d) in summer

$\begin{array}{lll}77 & 98.76 & 83.09\end{array}$

$\begin{array}{lll}93.74 & 84.91 \quad 55.16\end{array}$

100.1681 .86

\begin{tabular}{cccccccc} 
& 50.10 & -50.90 & 5 & -2708.20 & 0.00 & 0.31 & 0.08 \\
& 49.16 & -51.06 & 6 & -2707.13 & 0.21 & 0.28 & 0.09 \\
& & -50.92 & 4 & -2710.03 & 1.35 & 0.16 & 0.05 \\
& 50.46 & -50.38 & 6 & -2707.87 & 1.69 & 0.13 & 0.08 \\
& & -50.93 & 3 & -2711.40 & 1.88 & 0.12 & 0.03 \\
\hline
\end{tabular}

28.20

102.19 
Table 3. Plausible candidate models ( $\triangle \mathrm{AICc}<2)$ explaining current (1a) and long-term (1b) occurrence; and current (2a) and long-term (2b) abundance of

coefficient of determination based on the likelihood-ratio test $\left(R_{L R}^{2}\right)$ and Nagelkerke's pseudo-R-squared $\left(R_{N}^{2}\right)$ are presented

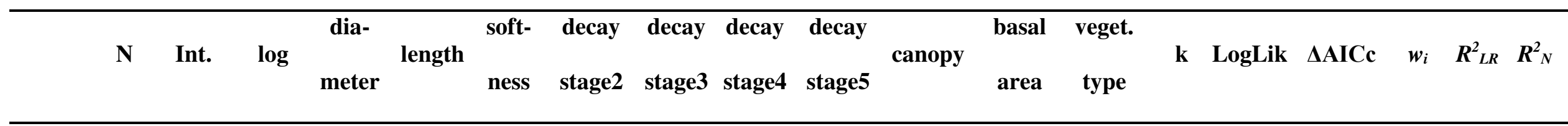

\section{Occurrence}

a) current

$\begin{array}{llllll}98 & -25.07 & 20.35 & 0.207 & 0.0011 & \\ -24.98 & 20.80 & 0.225 & 0.0009 & -0.145 \\ & -25.86 & 20.83 & 0.228 & 0.0010 & \end{array}$

$\begin{array}{llllllll}-0.371 & & 5 & -26.15 & 0.00 & 0.52 & 0.49 & 0.70 \\ -0.396 & & 6 & -25.65 & 1.27 & 0.27 & 0.50 & 0.71 \\ -0.353 & -0.575 & 6 & -25.91 & 1.79 & 0.21 & 0.50 & 0.71\end{array}$

b) long-term

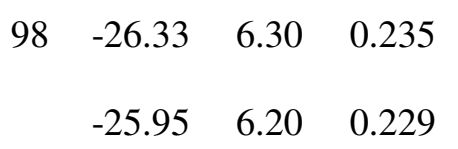

$\begin{array}{llll}16.79 & 18.18 & 16.89 & 18.49 \\ 16.83 & 18.13 & 16.64 & 18.35\end{array}$

$\begin{array}{ll}-0.390 & \\ -0.361 & -0.716\end{array}$

$\begin{array}{ll}8 & -24.96 \\ 9 & -24.62\end{array}$

0

$\begin{array}{lll}0.7 & 0.58 & 0.77\end{array}$

\section{Abundance}

a) current

\begin{tabular}{|c|c|c|}
\hline $29 \quad-1.10$ & 0.073 & \\
\hline-1.26 & 0.059 & 0.0003 \\
\hline
\end{tabular}

$\begin{array}{llllll}3 & -75.46 & 0.00 & 0.28 & 0.43 & 0.43 \\ 4 & -74.11 & 0.00 & 0.28 & 0.48 & 0.48\end{array}$




\begin{tabular}{|c|c|c|c|c|c|c|c|c|c|c|}
\hline-1.02 & 0.082 & & & & 2 & -77.00 & 0.58 & 0.21 & 0.37 & 0.37 \\
\hline-0.84 & 0.058 & 0.087 & & 0.247 & 4 & -74.91 & 1.60 & 0.12 & 0.45 & 0.45 \\
\hline-1.29 & 0.076 & 0.068 & 0.043 & & 4 & -75.06 & 1.91 & 0.11 & 0.45 & 0.45 \\
\hline
\end{tabular}

b) long-term

$\begin{array}{lllllllllllll}43 & 0.033 & 0.017 & 0.0002 & 0.121 & 0.020 & -0.081 & 6 & -204.89 & 0.00 & 1.00 & 0.89 & 0.89\end{array}$


Table 4. Plausible candidate models $(\triangle \mathrm{AICc}<2)$ explaining current $(1 \mathrm{a})$ and long-term (1b) occurrence; and current $(2 \mathrm{a})$ and long-term $(2 \mathrm{~b})$ abundance of Tragosoma depsarium in relation to microclimatic variables $\left(\mathrm{t}^{\circ} \mathrm{C}-\right.$ average temperature, $\mathrm{t}^{\circ} \mathrm{C}$ fluct. - daily temperature fluctuations, max $\mathrm{t}^{\circ} \mathrm{C}-\mathrm{maximum}^{\circ}$ temperature, RH \% - relative humidity). Sample size (N), intercept (Int.), number of parameters (k), model weight (wi), a coefficient of determination based on the likelihood-ratio test $\left(R^{2}{ }_{L R}\right)$ and Nagelkerke's pseudo-R-squared $\left(R^{2}{ }_{N}\right)$ are presented

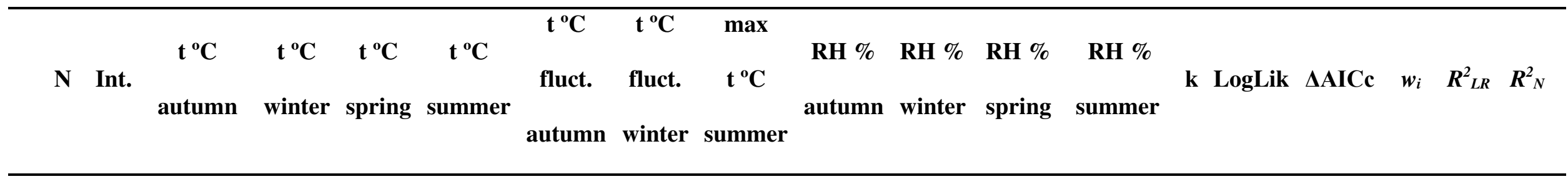

\section{Occurrence}

a) current

$\begin{array}{lll}77 & 6.95 & -1.915 \\ & 7.70 & -1.846 \\ & 6.76 & -2.011\end{array}$

$\begin{array}{ll}-2.330 & 0.323 \\ -2.33 & 0.325 \\ -2.41 & 0.318\end{array}$

$\begin{array}{lrrrrrr} & 4 & -33.74 & 0.00 & 0.51 & 0.49 & 0.62 \\ -0.013 & 5 & -33.24 & 1.30 & 0.27 & 0.49 & 0.63 \\ & 5 & -33.43 & 1.69 & 0.22 & 0.49 & 0.63\end{array}$

b) long-term

$\begin{array}{llll}77 & 3.31 & -3.14 & 0.743 \\ 2.94 & -2.91 & 0.638 \\ 1.77 & -2.99 & 0.495 \\ 2.03 & -3.14 & 0.811\end{array}$

$-0.325$

-0.03
-0.022
-0.03

$\begin{array}{lllllll}0.028 & 5 & -34.72 & 0.00 & 0.28 & 0.57 & 0.69 \\ & 4 & -36.04 & 0.35 & 0.23 & 0.55 & 0.67 \\ & 3 & -37.29 & 0.62 & 0.20 & 0.54 & 0.65 \\ 0.026 & 6 & -34.10 & 1.13 & 0.16 & 0.58 & 0.70\end{array}$




\begin{abstract}
$-0.9$
\end{abstract}
$-2.82$

0.635

\section{Abundance}

a) current

\begin{tabular}{|c|c|}
\hline 1.89 & \\
\hline 2.00 & \\
\hline 2.81 & \\
\hline 2.86 & \\
\hline 2.11 & \\
\hline 1.02 & \\
\hline 0.80 & \\
\hline 0.81 & \\
\hline 0.97 & \\
\hline 2.85 & -0.505 \\
\hline 2.18 & -0.329 \\
\hline 0.74 & \\
\hline
\end{tabular}

b) long-term

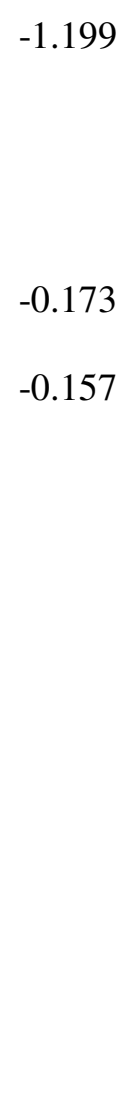

0.011

$\begin{array}{llllll}5 & -35.51 & 1.60 & 0.13 & 0.56 & 0.68\end{array}$

\begin{tabular}{|c|c|c|c|c|c|c|}
\hline & 3 & -63.23 & 0.00 & 0.11 & 0.83 & 0.83 \\
\hline 0.011 & 3 & -63.25 & 0.03 & 0.10 & 0.83 & 0.83 \\
\hline 0.009 & 3 & -63.30 & 0.14 & 0.10 & 0.83 & 0.83 \\
\hline \multirow[t]{5}{*}{0.012} & 3 & -63.33 & 0.19 & 0.10 & 0.83 & 0.83 \\
\hline & 3 & -63.34 & 0.21 & 0.10 & 0.83 & 0.83 \\
\hline & 3 & -63.35 & 0.23 & 0.09 & 0.83 & 0.83 \\
\hline & 3 & -63.55 & 0.64 & 0.08 & 0.83 & 0.83 \\
\hline & 3 & -63.60 & 0.73 & 0.07 & 0.83 & 0.83 \\
\hline \multirow[t]{3}{*}{0.012} & 3 & -63.71 & 0.96 & 0.07 & 0.82 & 0.82 \\
\hline & 3 & -63.90 & 1.33 & 0.05 & 0.82 & 0.82 \\
\hline & 3 & -64.00 & 1.53 & 0.05 & 0.82 & 0.82 \\
\hline 0.009 & 3 & -64.09 & 1.71 & 0.04 & 0.82 & 0.82 \\
\hline 0.009 & 3 & -64.21 & 0.96 & 0.04 & 0.82 & 0.82 \\
\hline
\end{tabular}




\section{Figure legends}

573 Fig 1. Location of study sites (black filled symbols) of Tragosoma depsarium, located close to four nature reserves (surrounded by dark grey line) and one conservation area (surrounded by light grey line)

575 Fig. 2 A schematic drawing of an identified study site, including four $\log s$ and one snag, with locations of new (triangles) and old (squares) exit-holes and data-loggers (circles)

577 Fig. 3 Average temperature in: (A) autumn in snags and logs in dry (black boxplots) and mesic (grey 578 boxplots) vegetation types; (B) winter in snags (black symbols) and $\operatorname{logs}$ (grey symbols) in relation to 579 basal area; (C) spring in relation to canopy openness; (D) summer in dry (black symbols) and mesic 580 (grey symbols) vegetation types in relation to canopy openness, expressing the main results of the first order models

582 Fig. 4 Predictive performance of models of current and long-term occurrence and abundance of $583 T$. depsarium in relation to deadwood characteristics, forest characteristics, the combination of 584 deadwood and forest characteristics, microclimatic variables, and the combination of deadwood and forest characteristics and microclimatic variables 
.

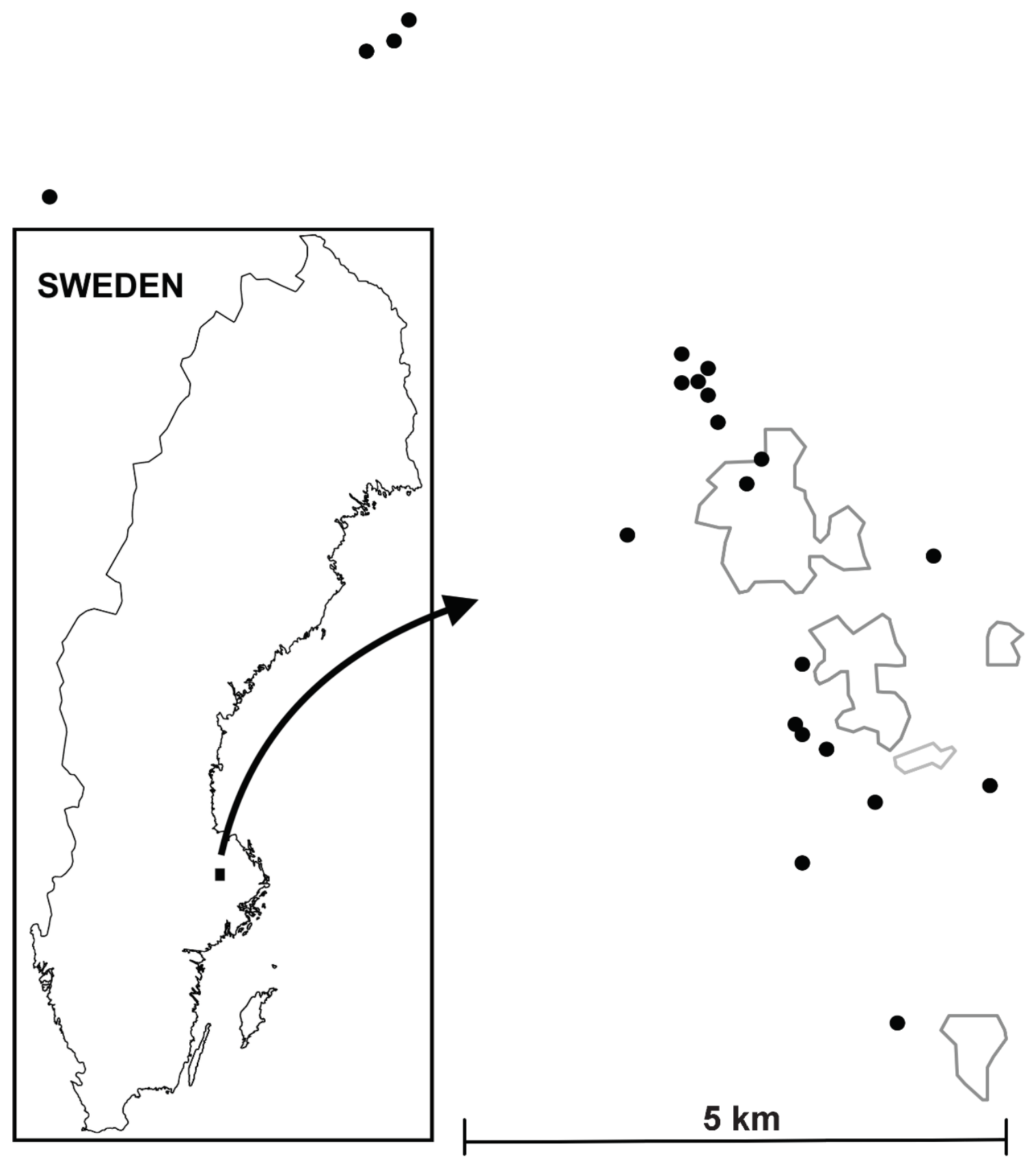

Fig. 1 


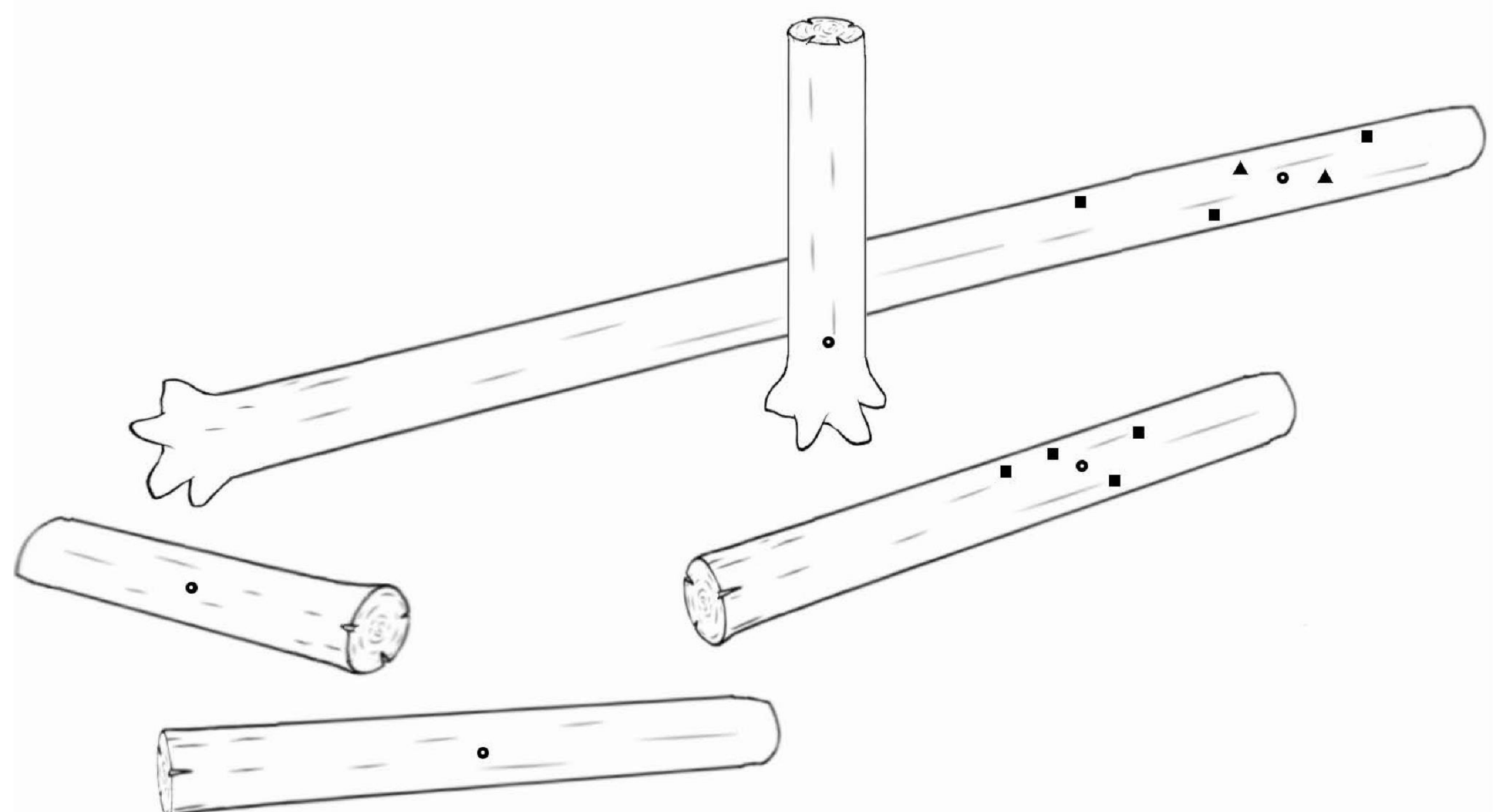

Fig. 2 
A

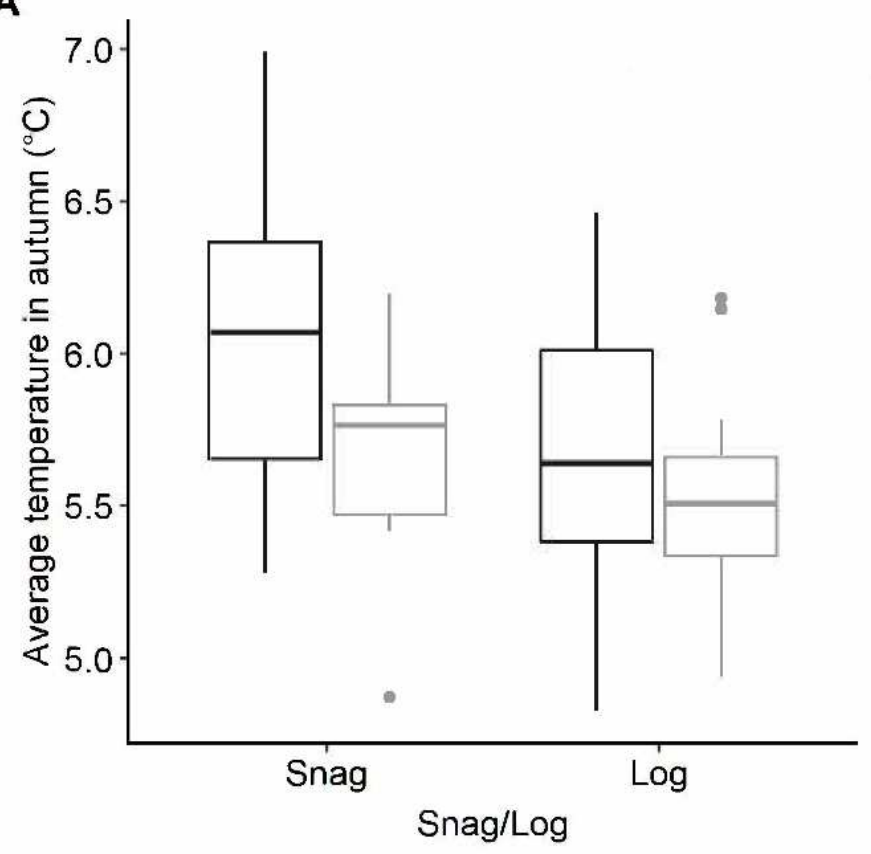

C

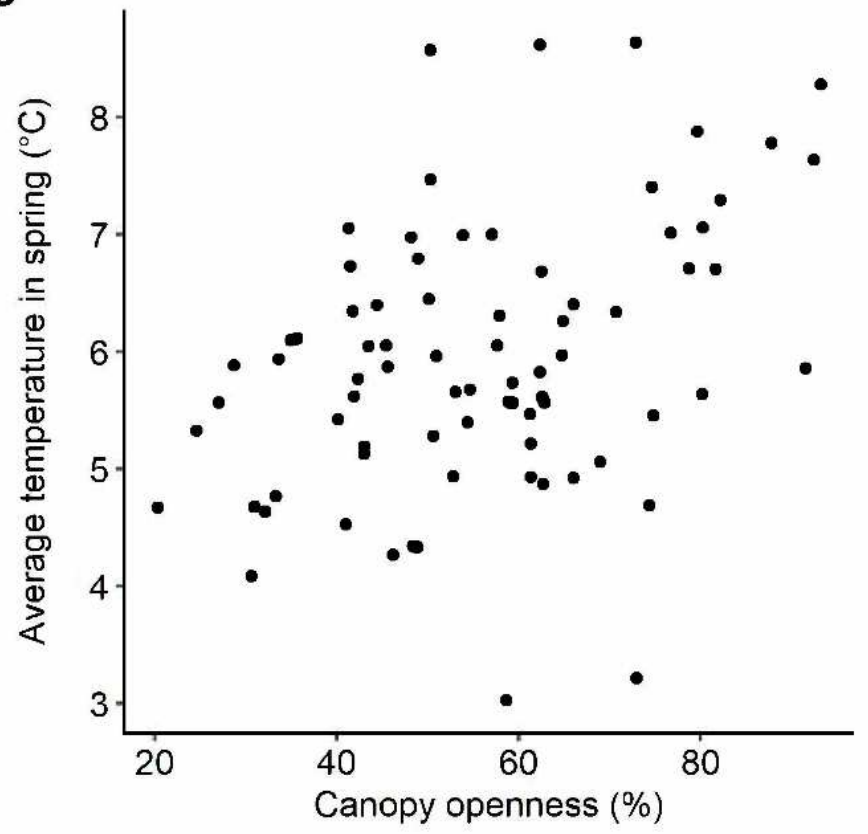

B

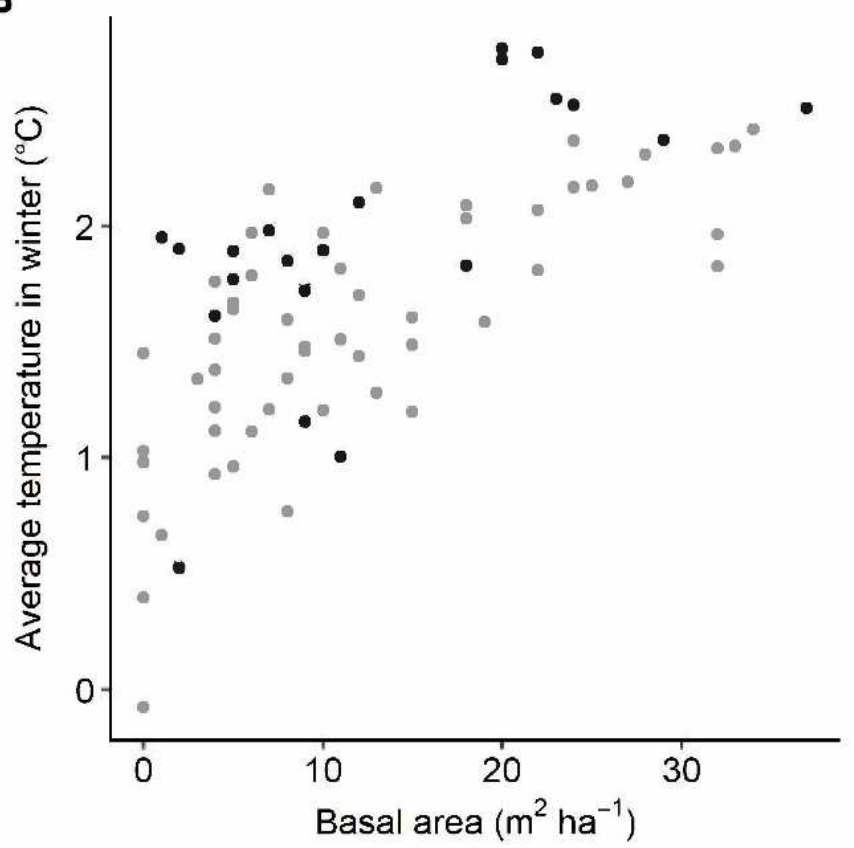

D

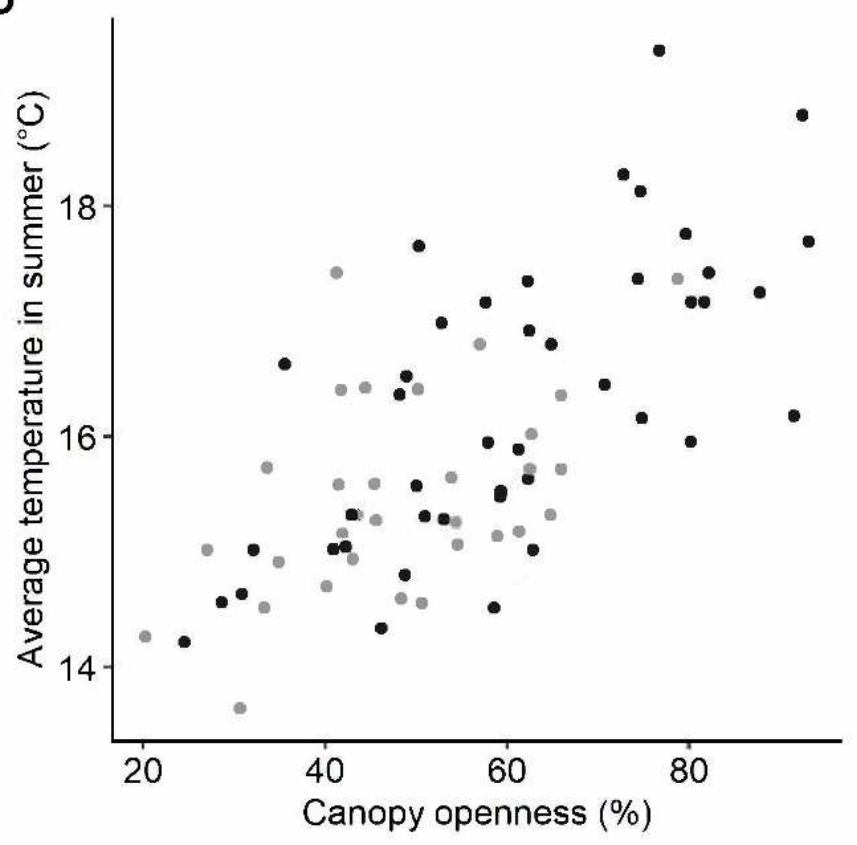

Fig. 3 


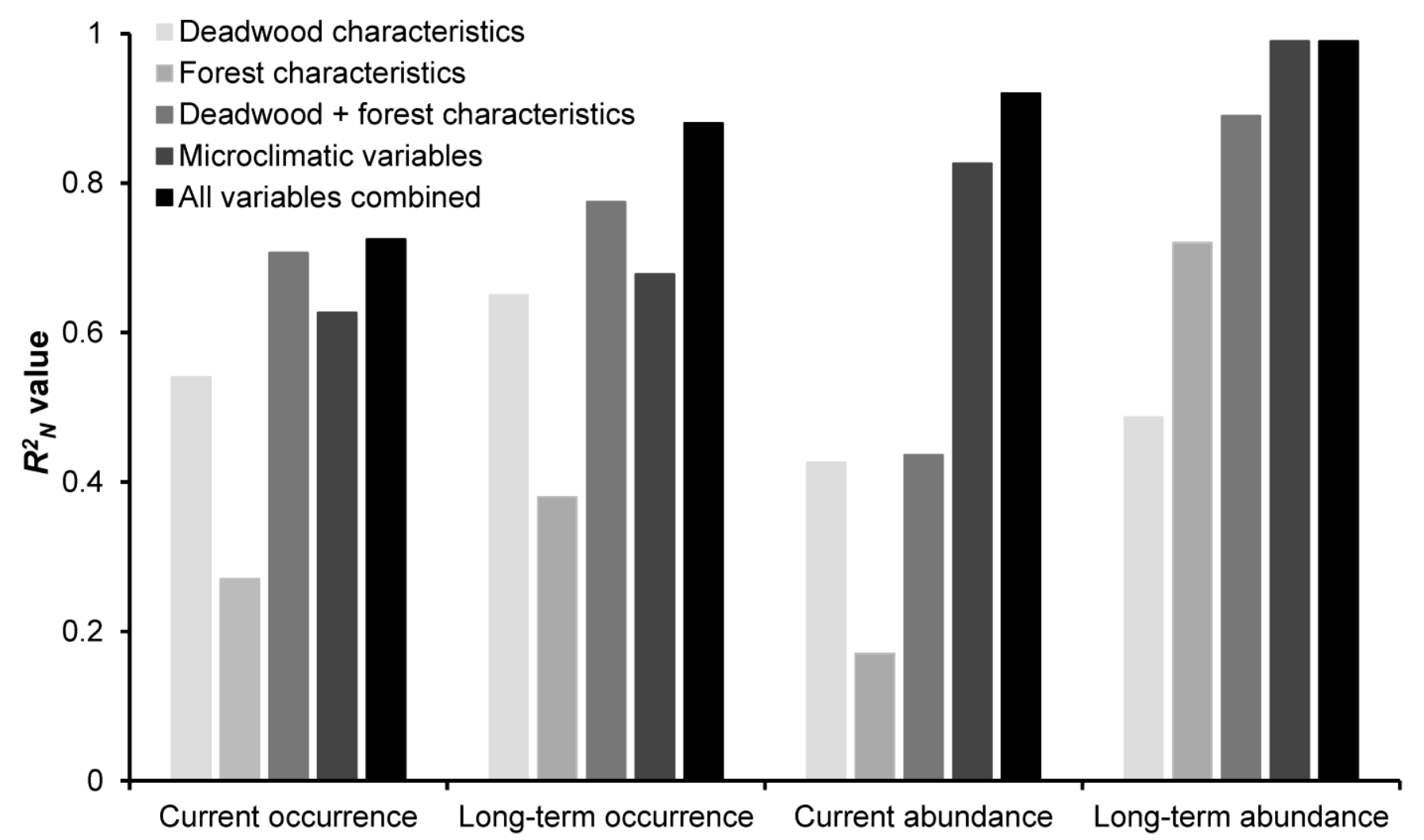

Analyses

Fig. 4 


\section{Supplementary Files}

This is a list of supplementary files associated with this preprint. Click to download.

- ESM1.pdf

- ESM2.pdf

- ESM3.pdf

- ESM4.pdf

- ESM5.pdf

- ESM6.pdf

- ESM7.pdf

- ESM8.pdf 